\title{
Haemophilus influenzae and smoking-related obstructive airways disease
}

This article was published in the following Dove Press journal:

International Journal of Chronic Obstructive Pulmonary Disease

15 June 2011

Number of times this article has been viewed

\section{Diana C Otczyk' \\ Robert L Clancy ${ }^{2}$ \\ Allan W Cripps'}

'School of Medicine, Griffith Health Institute, Griffith Health, Griffith

University, Gold Coast, Queensland, Australia; ${ }^{2}$ Immunology Unit, Hunter

Area Pathology Service and University of Newcastle, Newcastle, New South Wales, Australia
Correspondence: Allan W Cripps, School of Medicine, Griffith Health Institute, Gold Coast Campus, Griffith University, Queensland, 4222, Australia

Tel +6I (0)7 567807II

Fax +6I (0)7 56780795

Email allan.cripps@griffith.edu.au
Background: Intralumenal bacteria play a critical role in the pathogenesis of acute infective episodes and airway inflammation. Antigens from colonizing bacteria such as nontypeable Haemophilus influenzae (NTHi) may contribute to chronic lung disease through an immediate hypersensitivity response. The objective of this study was to determine the presence of specific NTHi-IgE antibodies in subjects with chronic bronchitis (CB) and COPD who had smoked.

Methods: Serum, sputum, and saliva samples were collected from subjects with $\mathrm{CB}$ and moderate-severe COPD and healthy aged-matched controls. Total IgE and specific NTHi IgE were measured by enzyme linked immmunosorbent assay. Throat swabs were examined for the presence of NTHi.

Results: The results demonstrate that: i) specific NTHi IgE antibodies occur at a low level in healthy subjects; ii) those with both $\mathrm{CB}$ and moderate-severe COPD have elevated specific NTHi IgE antibody compared with healthy controls, with higher levels in those with most severe disease; iii) IgE levels are greater in those with moderate-severe COPD than in those with CB. They demonstrate specific NTHi IgE antibody is regularly found at higher than normal levels in COPD.

Conclusion: The detection of IgE antibody to colonizing bacteria in all subjects with $\mathrm{CB}$ or moderate-severe COPD identifies a possible mechanism of bronchospasm in these subjects amenable to specific intervention therapy.

Keywords: nontypeable Haemophilus influenza, chronic bronchitis, chronic obstructive pulmonary disease, IgE, smoking

\section{Introduction}

Chronic airways disease related to inhalation of noxious material (smoking or environmental pollution) is a major health issue. In its extreme form, COPD is becoming an increasing cause of global mortality. ${ }^{1}$ COPD is characterized by progressive irreversible airflow limitation, and destruction of the gas exchange apparatus. These changes are associated with evidence of an inflammatory response ${ }^{2}$ characterized by cellular infiltrate, ${ }^{3}$ mucus secretion, ${ }^{4}$ and structural remodeling. ${ }^{5}$ While subjects can remain undiagnosed and without clinical evidence of lung disease until they have advanced COPD, many have a history of symptomatic disease evidenced as chronic cough and sputum (chronic bronchitis, CB) and/or recurrent episodes of acute wheezy bronchitis, and/or late onset reversible airways disease ('intrinsic asthma'). The relationship between these entities is complex and not well understood, with no obligatory linkage with COPD. A classical model identifies the extremes of 'completely reversible airways obstruction' (asthma) and irreversible 
airways obstruction (COPD), ${ }^{6}$ though clinical experience recognizes a more complex mixed picture. For example, airway hyper-responsiveness is commonly present in COPD contributing to symptoms such as breathlessness, wheeze, and increased cough. ${ }^{7}$ Linkage exists between smoking and recurrent acute wheezy bronchitis. ${ }^{8}$ Intrabronchial infection has been postulated as a major promoter of intrabronchial inflammation, ${ }^{9}$ with nontypeable Haemophilus influenzae (NTHi) as the most common and when present the most dominant pathogenic bacterium. ${ }^{9,10}$ A direct correlation exists between colonization of the lower airways, the level of airways obstruction, and cigarette smoking status. ${ }^{11} \mathrm{NTHi}$ directly damages the bronchus mucosa ${ }^{9}$ and is claimed to mediate acute infective episodes. ${ }^{12}$ Its role in causing progressive reversible or irreversible airways obstruction, however, remains debated. ${ }^{13,14}$ Recent studies indicate a critical role for colonizing NTHi in the pathogenesis of acute exacerbations of COPD and demonstrate that oral immunotherapy with NTHi reduces the level of colonization in the airways as well as the incidence and severity of acute exacerbations. ${ }^{15,16}$ The detection of higher levels of $\mathrm{IgE}$ in the serum of subjects with COPD, ${ }^{17}$ and the observation that NTHi triggers histamine release through both IgE- and nonIgE-dependent mechanisms ${ }^{18}$ from cells contained within the respiratory mucosal sensitized to the bacterium, ${ }^{19,20}$ suggests a role for NTHi also in the development of the reversible component of airways obstruction found in smoking-related airways disease. Detection of anti-bacterial IgE antibody and eosinophils in the bronchus lumen ${ }^{21}$ adds support to this concept that immediate hypersensitivity to colonizing bacteria contributes to bronchial disease. As detection of specific IgE antibody against NTHi antigens in airway secretions as well as blood is critical to the development of this hypothesis, two groups, one with $\mathrm{CB}$ and wheeze associated with acute exacerbations, and a second, with moderate-severe COPD, have been studied to determine the presence and amount of IgE anti-NTHi antibodies in blood, saliva, and sputum.

\section{Materials and methods Subjects}

Four groups of subjects were investigated: Group $1 \mathrm{CB}-11$ patients (23-61 years) $\geq 2$-year history of recurrent acute wheezy bronchitis, and chronic cough and sputum, defined as $\mathrm{CB}$ by the Medical Research Council (MRC). ${ }^{22}$ Control 1 - age matched for group 1: 9 healthy subjects with normal lung function. Group 2 moderate-severe COPD - 17 patients (44-77 years) with $\mathrm{CB}$ as defined by the $\mathrm{MRC}^{22}$ and the GOLD criteria for COPD. ${ }^{23}$ These subjects had chronic persistent irreversible airflow obstruction $\left(\mathrm{FEV}_{1}<80 \%\right.$ of predicted normal). Control 2 - age-matched for group 2: 9 healthy subjects with normal lung function. A clinical examination was made by a single consultant physician who assessed the subjects against the $\mathrm{MRC}^{22}$ and GOLD $^{23}$ criteria in a hospital outpatient clinic. A comprehensive questionnaire was administered by a study nurse. The questionnaire included data on smoking, allergic disease, and respiratory symptoms (as per the ATS-DLD78). Lung function was assessed by spirometry. Subjects were excluded if they had a history of long-standing asthma (other than episodic wheezing bronchitis). Wheeze was defined as a wheezing or whistling sound in the chest. None of the subjects studied had a respiratory infection within the preceding month of study, and all were clinically stable.

\section{Ethics approval and consent}

Ethical approval for the study protocol was provided by the University of Newcastle Human Research Ethics Committee. All subjects gave written informed consent.

\section{Samples collected}

Saliva was collected into chilled tubes by mild suction and clarified by centrifugation. Blood was collected by venipuncture, clotted, and the serum recovered by centrifugation. Sputum samples were obtained by a single expectoration during a morning visit to a hospital outpatient clinic and assessed for oropharyngeal contamination by microscopic examination. ${ }^{24}$ Only subjects whose sputum samples contained 4 or more squamous epithelial cells per low field were included in the study. Sputum sol was prepared from acceptable samples by centrifugation. The samples were frozen at $-70^{\circ} \mathrm{C}$ until analyzed. Throat swabs were collected. Sputum samples and throat swabs were cultured for NTHi.

\section{Measurement of total lgE and specific NTHi IgE antibodies}

Total IgE and specific NTHi IgE antibodies were measured by enzyme linked immunosorbent assay (ELISA). Goat antihuman IgE (Biosource International-Tago Immunochemicals, Camarillo, CA) was used as the solid phase antigen for the measurement of total IgE in samples. The solid phase antigens, an outer membrane protein (OMP) preparation, and P6, a highly conserved 16-kDa lipoprotein, used for the measurement of bacteria-specific IgE were prepared from NTHi prepared as previously described. ${ }^{23,25}$ Briefly, the OMP 
preparation was prepared by detergent solubilization of the outer membrane of the microbe and subsequent ethanol precipitation. P6 was prepared from the OMP preparation by preparative electrophoresis. The purity of the P6 antigen and the quality of the OMP preparation was characterized by sodium dodecyl-sulphate polyacrylamide gel electrophoresis (SDS-PAGE) carried out using the PHAST System (GE Healthcare, Buckinghamshire, UK). ${ }^{25,26}$ The P6 preparations were free of detectible bacterial endotoxin. The sensitivity range for total $\mathrm{IgE}$ was $0.15-2.43 \mathrm{ng} / \mathrm{mL}$. The between-assay coefficient of variation for both total $\operatorname{IgE}$ and specific NTHi IgE antibodies ranged from $6 \%-9 \%$. No cross-reactivity of the NTHi specific IgE ELISA was detected against other respiratory pathogens.

\section{Statistical analysis}

A Chi-square $\left(\chi^{2}\right)$ analysis was used to test for goodness of fit for each parameter measured. For data that were normally distributed analysis of differences between 2 individual groups were assessed by Student's $t$-test. The data were expressed as mean and standard error. Where the data were of nonparametric distribution, differences between groups were assessed by a Mann-Whitney nonparametric test. The results were expressed as median and range.

\section{Results}

\section{Subjects}

The subject groups were gender and age matched. None of the controls had smoked. Both the CB and COPD groups had a significant history of cigarette smoke exposure. Chest wheeze associated with acute bronchitis was characteristic of both the $\mathrm{CB}$ and COPD groups.

\section{Microbial culture}

Seventy percent of moderate-severe COPD subjects and $36 \%$ of CB subjects were throat swab culture positive for NTHi. Only 1 of the 18 control subjects was throat swab culture positive (Table 1). Fifty-six percent of moderatesevere COPD subjects and $66 \%$ of mild CB subjects had positive sputum cultures for NTHi.

\section{Total $\lg \mathrm{E}$}

In subjects with $\mathrm{CB}$ the levels of total $\mathrm{IgE}$ in saliva and serum were similar to those observed in Control 1 group. However, in patients with moderate-severe COPD the level of total IgE in saliva was significantly greater than in Control 2 group ( $8.5 \mathrm{vs} 4.0 \mathrm{ng} / \mathrm{mL}, P<0.005)$ and greater than that observed in the CB group ( 8.5 vs $5.0 \mathrm{ng} / \mathrm{mL}, P<0.05$ ). Total serum IgE was substantially elevated in moderatesevere COPD subjects compared with Control 2 group, but this did not reach statistical significance (992 vs $490 \mathrm{ng} / \mathrm{mL}$, $P=0.06)$. These serum levels were significantly greater than that observed in the mild COPD group (992 vs $438 \mathrm{ng} / \mathrm{mL}$, $P<0.05)$. In sputum, total IgE levels in both study groups were similar (11.5 vs $11.8 \mathrm{ng} / \mathrm{mL}$ ) (Table 2).

\section{NTHi specific lgE antibodies to OMP}

IgE NTHi OMP antibody was detected in the saliva, serum, and sputum of subjects with $\mathrm{CB}$ and in the serum of Control 1 group. Antibody levels in the serum of the CB

Table I Characteristics of study subjects

\begin{tabular}{|c|c|c|c|c|}
\hline Group & CB & Control I & COPD & $\overline{\text { Control } 2}$ \\
\hline Number of subjects & 11 & 9 & 17 & 9 \\
\hline Gender (M:F) & $7: 4$ & $5: 4$ & I I:7 & $6: 3$ \\
\hline \multicolumn{5}{|l|}{ Age (years) } \\
\hline Mean & 46.7 & 43.0 & 64.4 & 67.2 \\
\hline Range & $23-61$ & $23-62$ & $44-79$ & $52-77$ \\
\hline Current smokers & 9 & 0 & 2 & 0 \\
\hline Previously smoked & 2 & 0 & 15 & 0 \\
\hline Smoking exposure & 22 & 0 & 27 & 0 \\
\hline \multicolumn{5}{|l|}{ (cigarettes per day) } \\
\hline Wheezy bronchitis & 9 & 0 & 15 & 0 \\
\hline \multicolumn{5}{|l|}{ FEV $_{1}$ (L) } \\
\hline Mean & 2.59 & 2.50 & $0.50^{\mathrm{a}}$ & $1.94^{\mathrm{a}}$ \\
\hline Range & $1.18-4.75$ & $|.20-4.5|$ & $0.2-1.14$ & I.35-2.55 \\
\hline Throat swab NTHi positive & 4 & 0 & 12 & $\mathrm{I}$ \\
\hline Sputum NTHi positive & 6 & - & 9 & - \\
\hline
\end{tabular}

Note: ${ }^{\text {a }}<<0.005$.

Abbreviations: CB, chronic bronchitis; NTHi, nontypeable Haemophilus influenzae. 
Table 2 Total IgE, IgE to NTHi OMP, and IgE to NTHi P6 in the CB group, moderate-severe COPD group, Control I group, and Control 2 group

\begin{tabular}{|c|c|c|c|c|c|c|c|c|c|c|}
\hline & \multicolumn{6}{|c|}{ Clinical groups } & \multicolumn{4}{|c|}{ Age-matched healthy controls } \\
\hline & \multicolumn{3}{|l|}{$\overline{C B}$} & \multicolumn{3}{|l|}{ COPD } & \multicolumn{2}{|c|}{ Control I } & \multicolumn{2}{|l|}{ Control 2} \\
\hline & Saliva & Serum & Sputum & Saliva & Serum & Sputum & Saliva & Serum & Saliva & Serum \\
\hline \multicolumn{11}{|c|}{ Total lgE (ng/mL) } \\
\hline Mean \pm SE & $5.0 \pm 0.4^{*}$ & $438 \pm 100^{+}$ & $11.5 \pm 1.6$ & $8.5 \pm 1.2^{c, *}$ & $992 \pm 224^{+}$ & $11.8 \pm 1.7$ & $5.4 \pm 0.7$ & $401 \pm 92$ & $4.0 \pm 1.0^{c}$ & $490 \pm 118^{\circ}$ \\
\hline Median & 4.8 & 297 & $\mathrm{II} .4$ & 8.4 & 784 & 9.6 & 5.4 & 290 & 2.8 & 401 \\
\hline Range & $2.4-7.0$ & $13|-1| 72$ & $4.1-2 \mid .3$ & $2.2-20.6$ & II2-3822 & I.9-22.7 & $1.6-9.3$ & $210-1093$ & $1.1-9.4$ & $119-1,199$ \\
\hline \multicolumn{11}{|c|}{ OMP IgE (EUb/mL) } \\
\hline Mean \pm SE & $0.26 \pm 0.05$ & $79 \pm 14^{\mathrm{e}, \#}$ & $0.34^{\circ} \pm 0.9$ & $0.26 \pm 0.04$ & $257 \pm 54^{\mathrm{d}, \#}$ & $0.17^{\circ} \pm 0.04$ & $\mathrm{ND}^{\mathrm{a}}$ & $14 \pm 4^{\mathrm{e}}$ & $0.15 \pm 0.03$ & $15 \pm 3^{d}$ \\
\hline Median & 0.19 & 80 & 0.25 & 0.16 & 202 & 0.15 & & 12 & 0.13 & 15 \\
\hline Range & $0.11-0.66$ & $11-176$ & $0.11-1.16$ & $0.11-0.56$ & $33-801$ & $0.09-0.40$ & & $2-35$ & $0.08-0.27$ & $5-32$ \\
\hline \multicolumn{11}{|c|}{ P6 IgE (EU/mL) } \\
\hline Mean \pm SE & ND & $61 \pm 15^{f}$ & $0.33 \pm 0.6$ & ND & $182 \pm 43$ & ND & ND & $10 \pm 5^{f}$ & $\mathrm{ND}^{\mathrm{a}}$ & $86 \pm 36$ \\
\hline Median & & 36 & 0.25 & & 122 & & & 7 & & 55 \\
\hline Range & & $13-158$ & $0.21-0.67$ & & $3-523$ & & & $2-30$ & & $6-361$ \\
\hline
\end{tabular}

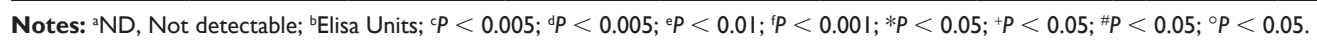

Abbreviations: CB, chronic bronchitis; ND, not detectable; NTHi, nontypeable Haemophilus influenzae; OMP, outer membrane protein; SE, standard error.

group were 5-fold greater than in Control 1 group (79 vs 14 Elisa Units $[\mathrm{EU}] / \mathrm{mL}, P<0.01)$. IgE NTHi OMP antibody was detected in all saliva, serum, and sputum samples in the moderate-severe COPD group and in all saliva and serum samples in Control 2 group. Salivary antibody levels were not significantly different. The level of antibody observed in the serum of the moderate-severe COPD group was 17-fold higher than that observed in Control 2 group (257 vs $15 \mathrm{EU} / \mathrm{mL}, P<0.005)$. IgE NTHi OMP antibody levels in the sputum of the $\mathrm{CB}$ group were twice that observed in the moderate-severe COPD group $(0.34$ vs $0.17 \mathrm{EU} / \mathrm{mL}$, $P<0.05$ ), while the level of antibody in the serum of the moderate-severe COPD group was $>3$-fold that observed in the CB group (257 vs $79 \mathrm{EU} / \mathrm{mL}, P<0.005$ ). A similar level of antibody was observed in the saliva of both clinical groups (Table 2).

\section{NTHi specific IgE antibodies to P6}

IgE NTHi P6 antibodies were not detected in the saliva of any group and only in the sputum of the CB group $(0.33 \mathrm{EU} / \mathrm{mL})$. In serum, IgE NTHi P6 antibodies tended to be highest in the moderate-severe COPD group with both the $\mathrm{CB}$ and COPD groups being higher than their respective controls. This was only significant for the CB group (61 vs $10 \mathrm{EU} / \mathrm{mL}$, $P<0.001$ ) (Table 2).

\section{Discussion}

This study aimed to assess the extent to which IgE antibody directed against NTHi antigens was present in smokers with recurrent acute bronchitis with either minimal or moderate-severe airways disease. Several characteristics were shared between these two groups. All were smokers or had recently smoked, and most had CB. While none had a long-standing history of 'asthma' or interval asthma, all but one had wheeze as part of their acute bronchitic episodes. The two groups differed in age and $\mathrm{FEV}_{1}$ as would be expected from the selection process.

In this cohort comparison study with age-matched controls without history of recurrent acute bronchitis, asthma, allergic disease, or smoking, 3 observations are made with respect to an IgE response to colonization with NTHi. First, in neither study group was there a significant difference between total IgE levels compared with age-matched controls. However, given that those with moderate-severe COPD have a median level twice that of the age-matched control group and a level significantly higher than that of the CB group, it is reasonable to conclude that continued intrabronchial inflammation over time is at least in part responsible for elevation in $\operatorname{IgE}$ noted in those with moderate-severe COPD. This concept is consistent with earlier finding ${ }^{27,28}$ and supported by the demonstrated increased upper respiratory tract colonization in this study. Second, there is detectable IgE antibody directed against NTHi OMPs in serum and saliva of normal subjects, using assays that include a mix of OMP antigens and the purified P6 protein, a specific and conserved NTHi antigen. ${ }^{29}$ This observation is consistent with studies that show both systemic and local immune response to NTHi in normal subjects detected as IgA and IgG antibody, ${ }^{30}$ as well as, T cell sensitization. ${ }^{31}$ The detection of specific NTHi IgE antibody in age matched controls indicates that IgE antibody 
is a component of the immune response to inhaled NTHi following intermittent colonization of the upper airways with antibody secreted from B lymphocytes within the bronchus mucosa. ${ }^{32}$ Third, specific antibody is increased in serum in both the CB and COPD groups compared with appropriate controls, with significantly higher anti-OMP IgE antibody in those with more severe disease. For the two study groups, the proportionate increase in specific antibody parallels the difference in total IgE levels. The finding of lower levels of specific NTHI IgE antibody in the sputum of the moderatesevere COPD group compared with the $\mathrm{CB}$ group may reflect the binding of IgE to the surface of respiratory cells and NTHi in subjects with a higher bacterial load, consistent with previous observations. ${ }^{19}$ Specific NTHi IgE antibody has been described in chronic airways disease, ${ }^{19,33}$ as has IgE antibody directed against other bacterial antigens. ${ }^{33-37}$ These earlier studies are largely isolated observations. Though limited to cross-sectional observations, the current study attempts to identify the profile of the immediate hypersensitivity response to NTHi by comparing subjects with mild and moderate-severe disease. Though these results may reflect change over time (and 'early' and 'late' smoking-related COPD), this study was not constructed to allow such conclusions, and it is recognized that not all with mild disease will progress to severe COPD. ${ }^{13,14}$

\section{What is the mechanism of increase in IgE and specific IgE antibody in smoking-related COPD?}

Smoking has been suggested as a cause of high IgE levels found in smokers; ${ }^{28}$ however, in the current study most of the moderate-severe COPD group were not smoking at the time of the study. The mechanisms by which smoking raises $\operatorname{IgE}$ levels and the duration of the effect are unknown. A likely explanation is that the elevated IgE responses observed in this study reflect colonization of damaged airways, possibly by a number of bacteria. ${ }^{38} \mathrm{NTHi}$ is the major pathogen colonizing damaged airways in $\mathrm{COPD}^{9,10}$ and acute exacerbations of COPD have been attributed to acquisition of 'exacerbation isolates' of $\mathrm{NTHi}^{39}$ and/or virus infection perturbing the host-parasite relationship involving NTHi. ${ }^{12,40}$ Many bacteria including NTHi stimulate polyclonal lymphocyte activation that could expand the IgE-secreting B cell population. ${ }^{41}$ Colonization of damaged airways by NTHi favors a Th2 cytokine response with production of IL- $4^{31,42,43}$ which, with IL-13, is expressed within the bronchus mucosa of smokers with CB. ${ }^{42}$ A sequence of signals involving IL-4 and IL-13 followed by interaction of the B cell surface antigen CD40 with its ligand (CD4OL) expressed on activated Th2 cells ${ }^{44}$ leads to IgE secretion.

\section{Does the production of $\lg E$ antibody to colonizing NTHi have clinical relevance?}

All forms of COPD commonly have a component of reversible airways obstruction, and bronchial hyper-reactivity is often present in COPD that is unrelated to classical atopic asthma. It is reasonable to accept that in those with specific NTHi IgE antibody, mucus hypersecretion, ${ }^{4}$ bronchial hyperreactivity, ${ }^{45}$ and bronchospasm due to a combination of events in the bronchus mucosa with mast cell degranulation ${ }^{46}$ and within the lumen with eosinophil degranulation, ${ }^{21,47}$ clinically significant reversible airways obstruction is a significant outcome. Oral immunotherapy of subjects with COPD with inactivated NTHi reduces the level of colonization of damaged airways by up to $3 \operatorname{logs},{ }^{48}$ significantly reduces the incidence of acute wheezing bronchitis in subjects with $\mathrm{CB},{ }^{8}$ reduces the severity of acute exacerbations, ${ }^{8,15,16}$ and reduces the use of antiasthma therapy (unpublished observations). There is also evidence to suggest that this therapeutic approach stimulates a Th1 type response against chronic microbial infections. ${ }^{49}$ Recently it was demonstrated that NTHi oral immunotherapy prevented NTHi from penetrating into the terminal airways, ${ }^{15}$ and this was correlated with an enhanced circulating specific antigen reactive $T$ cell response and a reduction in the level of salivary lysozyme, ${ }^{50}$ a marker of luminal inflammation in COPD. ${ }^{51}$ Prospective therapeutic studies aimed at reducing the intrabronchial load of NTHi, which correlate improvement of bronchial hyperreactivity and clinical bronchospasm with laboratory parameters of IgE-mediated hypersensitivity, are needed to determine more clearly the clinical relevance of specific IgE antibody in subjects with mild and severe COPD.

\section{Contributions}

All authors meet the criteria for authorship.

\section{Disclosure}

The authors declare no conflicts of interest.

\section{References}

1. Chronic obstructive pulmonary disease (COPD). Fact sheet No 315: World Health Organization; 2006.

2. Barnes PJ, Shapiro SD, Pauwels RA. Chronic obstructive pulmonary disease: molecular and cellular mechanisms. Eur Respir J. 2003;22: 672-688. 
3. Hargreave FE. Quantitative sputum cell counts as a marker of airway inflammation in clinical practice. Curr Opin Allergy Clin Immunol. 2007;7:102-106.

4. Hogg JC, Chu F, Utokaparch S, et al. The nature of small-airway obstruction in chronic obstructive pulmonary disease. $N$ Engl J Med. 2004;350:2645-2653.

5. Jeffery PK. Remodeling in asthma and chronic obstructive lung disease. Am J Respir Crit Care Med. 2001;164:S28-S38.

6. Pauwels RA. Similarities and differences in asthma and chronic obstructive pulmonary disease exacerbations. Proc Am Thorac Soc. 2004;1: 73-76.

7. Pauwels RA, Rabe KF. Burden and clinical features of chronic obstructive pulmonary disease (COPD). Lancet. 2004;364: 613-620.

8. Clancy RL, Cripps AW, Gebski V. Protection against recurrent acute bronchitis after oral immunization with killed Haemophilus influenzae. Med J Aust. 1990;152:413-416.

9. Sethi S, Murphy TF. Bacterial infection in chronic obstructive pulmonary disease in 2000: a state-of-the-art review. Clin Microbiol Rev. 2001;14:336-363.

10. Butt HL, Clancy RL, Cripps AW. Bacterial colonization of the respiratory tract in chronic bronchitis. Aust NZ J Med. 1990;20:35-38.

11. Zalacain R, Sobradillo V, Amilibia J, et al. Predisposing factors to bacterial colonization in chronic obstructive pulmonary disease. Eur Respir J. 1999;13:343-348.

12. Murphy TF. The role of bacteria in airway inflammation in exacerbations of chronic obstructive pulmonary disease. Curr Opin Infect Dis. 2006; 19:225-230.

13. Wedzicha JA. Airway infection accelerates decline of lung function in chronic obstructive pulmonary disease. Am J Respir Crit Care Med. 2001;164:1757-1758.

14. MacNee W. Airway infection does not accelerate decline in lung function in chronic obstructive pulmonary disease. Am J Respir Crit Care Med. 2001;164:1758-1760.

15. Tandon MK, Phillips M, Waterer G, Dunkley M, Comans P, Clancy R. Oral immunotherapy with inactivated nontypeable Haemophilus influenzae reduces severity of acute exacerbations in severe COPD. Chest. 2010;137:805-811.

16. Foxwell AR, Cripps AW, Dear KB. Haemophilus influenzae oral whole cell vaccination for preventing acute exacerbations of chronic bronchitis. Cochrane Database Syst Rev. 2006:4.

17. Renkema TE, Kerstjens HA, Schouten JP, Vonk JM, Koeter GH, Postma DS. The importance of serum IgE for level and longitudinal change in airways hyperresponsiveness in COPD. Clin Exp Allergy. 1998;28:1210-1218.

18. Clementsen P, Larsen FO, Milman N, Svok PS, Norn S. Haemophilus influenzae release histamine and enhance histamine release from human bronchoalveolar cells. Acta Pathol Microbiol Scand. 1995;103: 806-812.

19. Kjaergard LL, Larsen FO, Norn S, Clementsen P, Skov PS, Permin H. Basophil-bound IgE and serum IgE directed against Haemophilus influenzae and Streptococcus pneumoniae in patients with chronic bronchitis during acute exacerbations. Acta Pathol Microbiol Scand. 1996;104:61-67.

20. Norn S, Jensen L, Kjaergard LL, Permin H, Skov PS, Espersen F. Bacteria-induced IgE-mediated histamine release: examination of patients with chronic bronchitis (CB) during acute exacerbations. Agents Actions. 1994;41:C22-C23.

21. Saetta M, Di Stefano A, Maestrelli P, et al. Airway eosinophilia in chronic bronchitis during exacerbations. Am J Respir Crit Care Med. 1994;150:1646-1652.

22. Definition and classification of chronic bronchitis for clinical and epidemiological purposes. A report to the Medical Research Council by their Committee on the Aetiology of Chronic Bronchitis. Lancet. 1965;1:775-779.
23. Global Initiative for Chronic Obstructive Lung Disease. Pocket Guide to COPD diagnosis, management and prevention. A guide for physicians and nurses. In: National Health LaBI, ed. Bethesda: National Institutes of Health; 2006:1-88.

24. Courcol RJ, Damien JM, Ramon P, Voisin C, Martin GR. Presence of alveolar macrophanges as a criterion for determining the suitability of sputum specimens for bacterial culture. Eur J Clin Microbiol. 1984;3: 122-125.

25. Kyd JM, Taylor D, Cripps AW. Conservation of immune responses to proteins isolated by preparative polyacrylamide gel electrophoresis from the outer membrane of nontypeable Haemophilus influenzae. Infect Immun. 1994;62:5652-5658.

26. Kyd JM, Dunkley ML, Cripps AW. Enhanced respiratory clearance of nontypeable Haemophilus influenzae following mucosal immunization with P6 in a rat model. Infect Immun. 1995;63:2931-2940.

27. Shadick NA, Sparrow D, O'Connor GT, DeMolles D, Weiss ST. Relationship of serum IgE concentration to level and rate of decline of pulmonary function: the Normative Aging Study. Thorax. 1996; 51:787-792.

28. Sherrill DL, Halonen M, Burrows B. Relationships between total serum IgE, atopy, and smoking: a twenty-year follow-up analysis. J Allergy Clin Immunol. 1994;94:954-962.

29. Nelson MB, Munson RS Jr, Apicella MA, Sikkema DJ, Molleston JP, Murphy TF. Molecular conservation of the P6 outer membrane among strains of Haemophlius influenzae: analysis of antigenic determinants, gene sequences, and restriction fragment length polymorphisms. Infect Immun. 1991;59:2658-2663.

30. Cripps AW, Clancy RL, Murree-Allen K. Quantitation of isotype specific Haemophilus influenzae antibody serum and saliva of normal subjects and chronic bronchitis. Asian Pac J Allergy Immunol. 1986; 4:5-11.

31. King PT, Hutchinson PE, Johnson PD, Holmes PW, Freezer NJ, Holdsworth SR. Adaptive immunity to nontypeable Haemophilus influenzae. Am J Respir Crit Care Med. 2003;167:587-592.

32. Bienenstock J, McDermott MR. Bronchus- and nasal-associated lymphoid tissues. Immunol Rev. 2005;206:22-31.

33. Tee RD, Pepys J. Specific serum IgE antibodies to bacterial antigens in allergic lung disease. Clin Allergy. 1982;12:439-450.

34. Pauwels R, Verschraegen G, van der Straeten M. IgE antibodies to bacteria in patients with bronchial asthma. Allergy. 1980;35:665-669.

35. Rohde G, Gevaert P, Holtappels G, et al. Increased IgE-antibodies to Staphylococcus aureus enterotoxins in patients with COPD. Respir Med. 2004;98:858-864.

36. Shen J, Brackett R, Fischer T, Holder A, Kellogg F, Michael JG. Specific Pseudomonas immunoglobulin $\mathrm{E}$ antibodies in sera of patients with cystic fibrosis. Infect Immun. 1981;32:967-968.

37. Bloom JW, Halonen M, Dunn AM, Pinnas JL, Burrows B. Pneumococcus-specific immunoglobulin E in cigarette smokers. Clin Allergy. 1986;16:25-32.

38. Hill AT, Campbell EJ, Hill SL, Bayley DL, Stockley RA. Association between airway bacterial load and markers of airway inflammation in patients with stable chronic bronchitis. Am J Med. 2000;109:288-295.

39. Fernaays MM, Lesse AJ, Sethi S, Cai X, Murphy TF. Differential genome contents of nontypeable Haemophilus influenzae strains from adults with chronic obstructive pulmonary disease. Infect Immun. 2006;74:3366-3374.

40. Anzueto A, Sethi S, Martinez FJ. Exacerbations of chronic obstructive pulmonary disease. Proc Am Thorac Soc. 2007;4:554-564.

41. Montes CL, Acosta-Rodriguez EV, Merino MC, Bermejo DA, Gruppi A. Polyclonal B cell activation in infections: infectious agents' devilry or defense mechanism of the host? J Leukoc Biol. 2007;82: 1027-1032.

42. Miotto D, Ruggieri MP, Boschetto P, et al. Interleukin-13 and -4 expression in the central airways of smokers with chronic bronchitis. Eur Respir J. 2003;22:602-608. 
43. Zhu J, Majumdar S, Qiu Y, et al. Interleukin-4 and interleukin-5 gene expression and inflammation in the mucus-secreting glands and subepithelial tissue of smokers with chronic bronchitis. Lack of relationship with CD8(+) cells. Am J Respir Crit Care Med. 2001;164: 2220-2228.

44. Bacharier LB, Geha RS. Molecular mechanisms of IgE regulation. J Allergy Clin Immunol. 2000;105:S547-S558.

45. Tracey M, Villar A, Dow L, Coggon D, Lampe FC, Holgate ST. The influence of increased bronchial responsiveness, atopy, and serum $\operatorname{IgE}$ on decline in FEV1. A longitudinal study in the elderly. Am J Respir Crit Care Med. 1995;151:656-662.

46. Ekberg-Jansson A, Amin K, Bake B, et al. Bronchial mucosal mast cells in asymptomatic smokers relation to structure, lung function and emphysema. Respir Med. 2005;99:75-83.
47. Saha S, Brightling CE. Eosinophilic airway inflammation in COPD Int J Chron Obstruct Pulmon Dis. 2006;1:39-47.

48. Lehmann D, Coakley KJ, Coakley CA, et al. Reduction in the incidence of acute bronchitis by an oral Haemophilus influenzae vaccine in patients with chronic bronchitis in the highlands of Papua New Guinea. Am Rev Respir Dis. 1991;144:324-330.

49. Dunkley M, Pabst R, Cripps A. An important role for intestinally derived T cells in respiratory defence. Immunol Today. 1995;16:231-236.

50. Clancy R, Dunkley M. Oral non-typable Haemophilus influenzae enhances physiological mechanism of airways protection. Clin Exp Immunol. 2010;161:127-133.

51. Taylor DC, Cripps AW, Clancy RL. A possible role for lysozyme in determining acute exacerbation in chronic bronchitis. Clin Exp Immunol. 1995;102:406-416.

\section{Publish your work in this journal}

The International Journal of COPD is an international, peer-reviewed journal of therapeutics and pharmacology focusing on concise rapid reporting of clinical studies and reviews in COPD. Special focus is given to the pathophysiological processes underlying the disease, intervention programs, patient focused education, and self management protocols.

\section{Dovepress}

This journal is indexed on PubMed Central, MedLine and CAS. The manuscript management system is completely online and includes a very quick and fair peer-review system, which is all easy to use. Visit http://www.dovepress.com/testimonials.php to read real quotes from published authors.

Submit your manuscript here: http://www.dovepress.com/international-journal-of-copd-journal 